DOI: 10.20472/IAC.2018.935.014

JOLANTA DROZDZ

Vilnius University, Lithuania

\title{
MARKET OPENNESS AND LITHUANIAN AGRIFOOD TRADE IN THE CONTEXT OF CHANGING TRADE CONDITIONS
}

\begin{abstract}
:
The multilateral trade liberalisation process has gradually transformed into regionalism where countries initiate bilateral, interregional agreements. Regional integration of separate countries, regions or groups of countries has also become stronger. Deeper economic integration of the countries has changed the conditions of international trade. Timely adaptation to the change in the international trade conditions is the essential condition of sustainable development of international trade linked to the more rapid economic growth of countries. The paper performs the Lithuanian agricultural and food sector in the changing international trade conditions during the period of 1999-2014. Analysis of the international trade of Lithuanian agricultural and food products divided into three phases. The first phase covers the period from 1999 to 2003 (before Lithuania's accession to the EU). The second phase covers the period from 2004 to 2008 (trade peak since joining the EU by 2008 the global economic crisis). In addition, the third stage includes the period from 2009 to 2014 (recovery after the crisis period). Market openness effect on agrifood trade of Lithuania measured by Open Trade Index (OTI). OTI formula adopted for agricultural sector performance analysis. The net effect of the EU membership evaluated. Suggested approach shows the complexity of the international trading system and specifies the further development of export direction.
\end{abstract}

\section{Keywords:}

market openness, trade liberalisation, agrifood trade, economic integration

JEL Classification: F15, F41, F43 


\section{Introduction}

The free and open trade paradigm, which inspired by the classic economists (Smith, 1776; Ricardo, 1821) has evolved (Heckscher, Ohlin, 1919; Stolper, Samuelson, 1941) and supplemented by the foresights of the new trade theory (Krugman, 1979). The economists have unanimously agreed that the free trade, i.e. trade without restrictions, will promote international trade development and economic growth. However, they have explained the impact of the free trade on economics differently. The contemporary international trade theories put emphasis on the benefits, recommend new ways of organisation of international trade (for example, creation of the global value chains (Baldwin, 2014) where different production processes are carried out in different countries). The advantages of free trade should encourage facilitation of the conditions of international trade, but multilateral trade liberalisation process has remained trapped in the context of negotiations of the World Trade Organisation (WTO). The detailed analysis of the scientific literature justifies and outweighs the benefit of free trade as compared with any manifestations of protectionism (Droždz, Miškinis, 2011). The most significant impact of trade liberalisation is observed at country's level. Open market access, trade creation leads to faster economic growth, which is the main factor of welfare increase. It also creates favourable conditions for business start-up and development, which is additional impetus for investments and production growth.

The liberalization of international trade has had an impact on the processes of globalization, which has led to the integration of countries. One of the most important aspects in the global and mutually integrated world is the spread of regional trade agreements. The regionalization process intensified in 1990 and marked not only the elimination of trade barriers, but also investment protection, general competition policy, intellectual property protection and other aspects (Damuri, 2012).

The international commercial policy pays special attention to agricultural sector due to the specific nature of the sector, dependence of the sector on natural conditions and other aspects. In Europe and elsewhere in the world, more and more scientific works are devoted analysing the effects of trade openness and globalisation on agriculture, including the analysis of the globalisation of agricultural trade (Poczta-Wajda, 2014; Bojnec, Fertő, 2014; Molendowski, 2014; Vinciūnienè, Dadurkaitè, 2011; Laskienè, 2010; Anderson, 2010). In addition, studies by the aforementioned authors show that global agricultural integration in the form of trade is relatively selective and has a different reciprocal impact on individual countries and regions in agriculture. Therefore, it is important to examine the impact of market openness processes on a small open economy, like Lithuania, in particular on the agricultural and food sector.

Exports of agricultural and food products of Lithuania makes around one fifth of the total exports; thus, the latter sector is important to the national economy. Lithuania as a small 
open economy country is particularly sensitive to external shocks. The European Union (EU) acts as a unit in bilateral or multilateral negotiations over free trade agreements and this does not always satisfy the specific needs and interests of separate EU Member States including Lithuania. The carried out research is intended for assessing the changes in the international trade conditions and evaluating the impact of such changes on the exports of agricultural and food products of Lithuania. Regarding to that, several tasks carried out:

- To investigate the main stages of the changes in the international trade conditions of Lithuania.

- To measure up the overall level of Lithuanian market openness, as well as an openness of agricultural and food sector market of Lithuania.

- $\quad$ To distinguish the level of market openness effect due to Lithuanian membership in the WTO and the EU.

\section{Methods}

Analysis based on country's case covers periods before and after the accession to the EU, when all legal regulating system on international trade became centralized. The period 1999-2014 was chosen for the comparison of trade volume dynamics and common structure of agricultural and food exports. The secondary statistical analysis, using historical comparative method helped to explore the development trends of agricultural and food products exports of Lithuania. The data from Lithuanian Department of Statistics used for the analysis. In addition, the regression and trend analysis used.

Market openness performs benefits for the economy and fosters the development of international trade. One of the trade development channels is exports. Economic openness shows that the country could be sensitive to external shocks, which may affect trade volumes and cause the economic slowdown. Economic openness measured with Open trade index, as the sum of exports and imports ratio in GDP:

$$
\mathrm{OTI}=(\mathrm{X}+\mathrm{M}) / \mathrm{GDP}
$$

Where, $X$ - exports; $M$ - imports; GDP - Gross domestic product

Economic openness indicates that a country can be sensitive to external shocks, which may have an impact on the decline in trade volumes and the slowdown in economic growth. It allow to determine at what level international trade in agricultural and food sector of Lithuania contributes to maintaining market openness or, conversely, restricts the openness of international trade of the country through protectionist measures of international trade. 
Author suggested adjusting formula to measure openness in agricultural and food sector. It measures the sum of the exports and imports of agricultural and food products as ratio of gross value added created in agriculture:

$$
\mathrm{OTI}_{\mathrm{a}}=\left(\mathrm{X}_{\mathrm{a}}+\mathrm{M}_{\mathrm{a}}\right) / \mathrm{GVA} \mathrm{A}_{\mathrm{a}}
$$

Where, $X_{a}$ - exports of agricultural and food products, $M_{a}$ - imports of agricultural and food products, $G V A_{a}$-Gross Value Added in agriculture and food sector.

In order to assess precisely the net impact of the EU integration of agricultural and food products export of Lithuania development, it is generally necessary to eliminate the previous trade liberalization processes in the Baltic countries and the impact of the WTO membership. It is therefore proposed initially assess how they developed if Lithuania not became a member of the EU in 2004. For that reason Lithuanian agricultural and food export forecasts after 2003 prepared. The time-line trend model explored the extent of integration effect to the agricultural and food products exports of Lithuania. It assumed that a future export is driven by the trends of the past, so the estimated time trend model used to forecast exports. The resulting trend equation was as follows: $X_{t}=552.1-$ $57.1 \mathrm{t}+8.9 \mathrm{t}^{2}$; determination coefficient $\mathrm{R}^{2}=0.56$ performs a good description of the data.

\section{Main stages of the changing trade conditions in Lithuania}

Changes in international trade conditions in Lithuania refer to several important dates. First important date was the $11^{\text {th }}$ of March 1990, when the independence of Lithuania restored. Active trade liberalization processes started in 1993, significant changes in national legislation appeared. Later on, Lithuania, as an independent country, sought to be established on the international arena and to become a member of the most important international organizations, like WTO and later the EU.

The scientific literature identifies four main stages of development of the Lithuanian international trade conditions (Travkina, 2015; Travkina, Tvaronavičienè, 2011). Current paper distinguishes six main stages of change of the internal trade of Lithuania since 1990, groups the stages according to the specific features of separate stages. Every stage continues on average five years (Table 1).

Restoration of Lithuanian independence in 1990 led to radical political, economic and social changes. Changes in foreign trade conditioned by change of economic policy and new agreements. Specifically, foreign trade liberalized due to a number of unilateral decisions and treaties, which created the current Lithuanian foreign trade regime and trade policy structure. A bilateral and regional free trade agreement, particularly with the EU and the two other Baltic countries (Latvia and Estonia), was another important step in the development of Lithuania's foreign trade policy.

Changes in customs tariffs on export/import of Lithuanian goods to/from the EU took place even before the accession to the EU, whereas, following the Europe Agreement 
establishing an association between the European Communities and its Member States on the one hand and the Republic of Lithuania on the other hand, a one-sided reduction of the EU customs tariffs on goods of Lithuanian origin was started as of 1995, and by the year 2001 all duties on the non-agricultural products were eliminated by the Lithuanian side.

Table 1: Lithuania's international trade conditions after the year 1990

\begin{tabular}{|c|c|c|c|}
\hline Period & $\begin{array}{c}\text { Content of international trade } \\
\text { conditions } \\
\end{array}$ & $\begin{array}{c}\text { Negotiating } \\
\text { directions }\end{array}$ & Stage \\
\hline 1990-1995 & $\begin{array}{l}\text { Trade liberalization with the Baltic } \\
\text { States, the European Economic } \\
\text { Community, restored national currency, } \\
\text { which is linked to the US dollar }\end{array}$ & $\begin{array}{l}\text { The Baltic States } \\
\text { European } \\
\text { Economic } \\
\text { Community } \\
\end{array}$ & $\begin{array}{l}\text { Adaptation of the } \\
\text { legal regulation }\end{array}$ \\
\hline 1995-1999 & $\begin{array}{l}\text { Application for admission to the EU, } \\
\text { signed Multilateral Framework } \\
\text { Agreement on Tariffs and Trade; official } \\
\text { invitation to EU negotiations; The EU } \\
\text { unilaterally withdrew import duties for } \\
\text { goods of Lithuanian origin; non-tariff } \\
\text { barriers to trade from Lithuania; export } \\
\text { subsidies have been introduced. }\end{array}$ & $\begin{array}{c}\text { Negotiations with } \\
\text { the EU and the } \\
\text { WTO }\end{array}$ & $\begin{array}{l}\text { Preparation for } \\
\text { membership to the } \\
\text { EU and the WTO }\end{array}$ \\
\hline 2000-2003 & $\begin{array}{l}\text { All import duties for non-agricultural } \\
\text { products eliminated by } 2001 \text {, the } \\
\text { average import tariff rate reduced, and } \\
\text { export subsidies abandoned, WTO } \\
\text { membership, national currency linked } \\
\text { to the euro. }\end{array}$ & WTO membership & Warming up \\
\hline 2004-2008 & Export subsidies are introduced & \multirow{2}{*}{ EU membership } & Active growth \\
\hline 2009-2013 & $\begin{array}{l}\text { The period of recovery after the global } \\
\text { economic crisis }\end{array}$ & & $\begin{array}{l}\text { Adapting to new } \\
\text { conditions }\end{array}$ \\
\hline Nuo 2014 & $\begin{array}{l}\text { Russian embargo on agricultural and } \\
\text { food products; canceled export } \\
\text { subsidies; diversification of international } \\
\text { trade in agricultural and food products }\end{array}$ & $\begin{array}{c}\text { Trade } \\
\text { liberalization } \\
\text { negotiations at EU } \\
\text { level }\end{array}$ & Qualitative coup \\
\hline
\end{tabular}

Source: own contribution. 
On the 31th of May 2001, Lithuania acceded to the WTO and became its $141^{\text {st }}$ member. The status of a Member in this organisation not only led to international recognition but also brought real benefits such as larger foreign investment flows, new markets for national exporters and their increased reliability in markets of the WTO member states. Upon accession to the WTO, Lithuania also obtained the right to defend its commercial interests both through involvement in the process of further liberalisation of global trade and negotiations regarding more favourable trade conditions with acceding countries to the WTO (European Commission, 2013).

It is noteworthy that membership in the WTO has contributed to successful accession to the EU in view of the fact that WTO membership is one of the most important aspects of the EU acquis in the area of external relations. From the $1^{\text {st }}$ of May 2004, Lithuania applied EU contractual relations with third countries and international organizations. Thus, the foreign trade policymaking delegated to the Council and the European Commission as Republic of Lithuania joined the EU common trade policy area. Enlargement of the EU has opened additional opportunities for business in Lithuania as it joined the common market, with more than 450 million consumers.

\section{Market openness effect on agrifood trade of Lithuania}

Statistical analysis of the international trade of agricultural and food products of Lithuania divided into three phases. The first phase covers the period from 1999 to 2003 (from the earliest available comparable statistics until the year before Lithuania's accession to the EU). The second phase covers the period from 2004 to 2008 (trade peak since joining the EU by 2008 the global economic crisis). In addition, the third stage includes the period from 2009 to 2014 (recovery after the crisis period).

Agricultural and food product exports of Lithuania in 1999-2003, have been in certain stagnation and trade balance was negative. Since 2004, agricultural and food product exports gained momentum and began to grow rapidly, reaching a value of 4644 million EUR in 2014. Lithuanian agricultural and food exports value increased twice from 2009 to 2014. Over the lifetime of the EU membership, this indicator increased by more than five times in 2014 compared to 2004. Agricultural and food imports grew at a slower rate during the same period, although it increased and reached its value of 3706 million EUR in 2014. It was more than 4 times higher than in 2004. International trade in agricultural and food products balance reached a record of 939 million EUR in 2014, in other words, a one fifth of the total agricultural and food exports.

Lithuanian origin agricultural and food products throughout the agricultural and food product exports accounted for 90 percent in 1999. This tendency preserved up to the accession to the EU. Later it began to decline, and counted only 65 percent in 2014. It 
was obvious that Lithuania has become the gateway from the West to the East for the agricultural and food exports.

The assessment of Lithuanian origin exports reveals alarming trend of rapidly increasing share of primary agricultural commodities and the exports of processed food products falling. This tendency became apparent after 2008. The increasing grain harvest and relatively easy and fast realization of it on the world market partially explain this trend. However, this trend persists in the long run, it is necessary to analyse the details of exports of Lithuanian origin agricultural and food products and to clarify the relationship between the reasons why these processes take place.

Assessing the sectoral point of view there were many structural changes in agricultural and food product exports during the analysed period. Livestock products dominated in the export structure by the Lithuanian membership in the EU. This trend reversed in favour of the plant products since 2004. The main exported agricultural and food products from Lithuania to the world were dairy products, tobacco and cereals in 2003. These three groups accounted for almost half of the total Lithuanian agricultural and food exports. Lithuanian agricultural and food export structure diversified in 2014. Four main exported product groups appear, like milk and milk products, eggs and honey; cereals; edible fruits and nut; and edible vegetables. These groups accounted for about 44 per cent of the total Lithuanian agricultural and food exports.

After the restoration of independence, the reforms have essentially changed the economic relations of Lithuania with other countries. Joining the WTO, signing free trade agreements with many countries, creating conditions for the free movement of capital to and from Lithuania allows us to state that Lithuania has become an open economy. In the open and small countries, the development of foreign trade, especially exports, is one of the important factors for stable economic growth.

Formula adapted for sectoral analysis allowed determining that Lithuanian agricultural sector has contributed to the creation of an open market; has not introduced hidden market protection measures; and exporters successfully integrated into the EU single market. The decrease in the OTla index in years 2008-2012 confirms the fact that a small open economy, like Lithuania, liberalizing trade in agricultural and food products has become more vulnerable and dependent on the world processes (Figure 1). Small country lacks a sufficient domestic consumption to absorb external shocks. 
Figure 1: Open trade index for all trade (OTI) and agricultural and food sector $(\mathrm{OTI})$ (1999-2014)

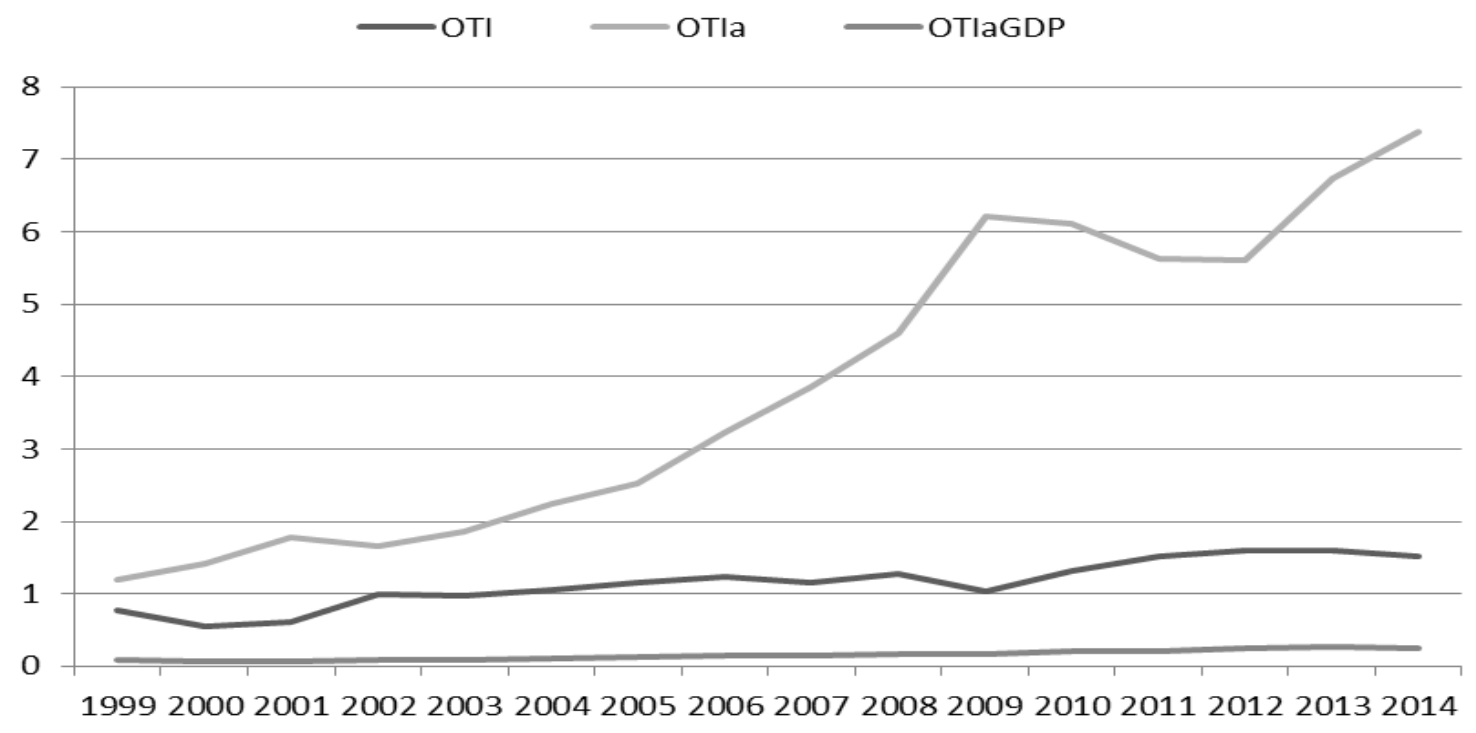

Source: own calculations based on Department of Statistics of Lithuania, 2015.

Both export and import volumes increased in absolute terms since 2004 after the EU accession, however, the value added created in agriculture changed only marginally, even fell during the 2009 global financial crisis. Indeed, a two-way trend observed. On the one hand, the agricultural and food exports and imports as a percentage of GDP are growing, on the other hand, the agricultural and food industry sector in the relative weight of GDP is steadily declining because of the vertical diversification of the economy (Figure 2). Low value added in agriculture indicates not effective investment support to the agricultural sector and other problems faced by the agricultural and food sector of Lithuania in the face of global competition. 
Figure 2: Exports, imports of agricultural and food products of Lithuania and value added in agriculture (1999-2014, mio. EUR)

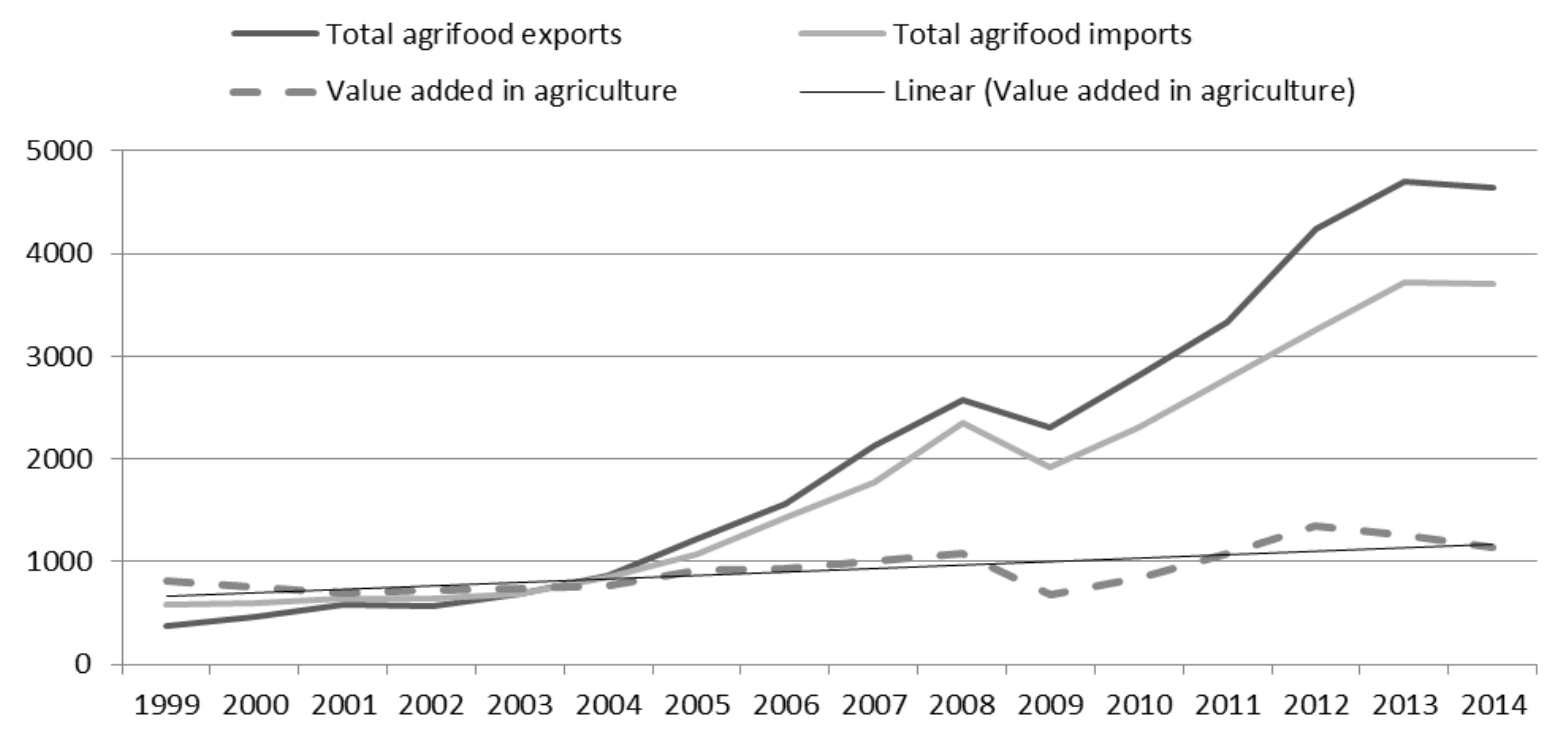

Source: own calculations based on Department of Statistics of Lithuania, 2015.

Lithuania's accession to the WTO in 2001 (global integration) and the EU in 2004 (regional integration) - the most significant events of the first decade of the twenty-first century that paved the way for agricultural and food exports to grow, accelerated trade liberalization processes in the country since the restoration of independence in 1999.

Figure 3: Actual exports and the net effect of the EU membership on the Lithuanian agricultural and food exports in years (1999-2013, mio. EUR)

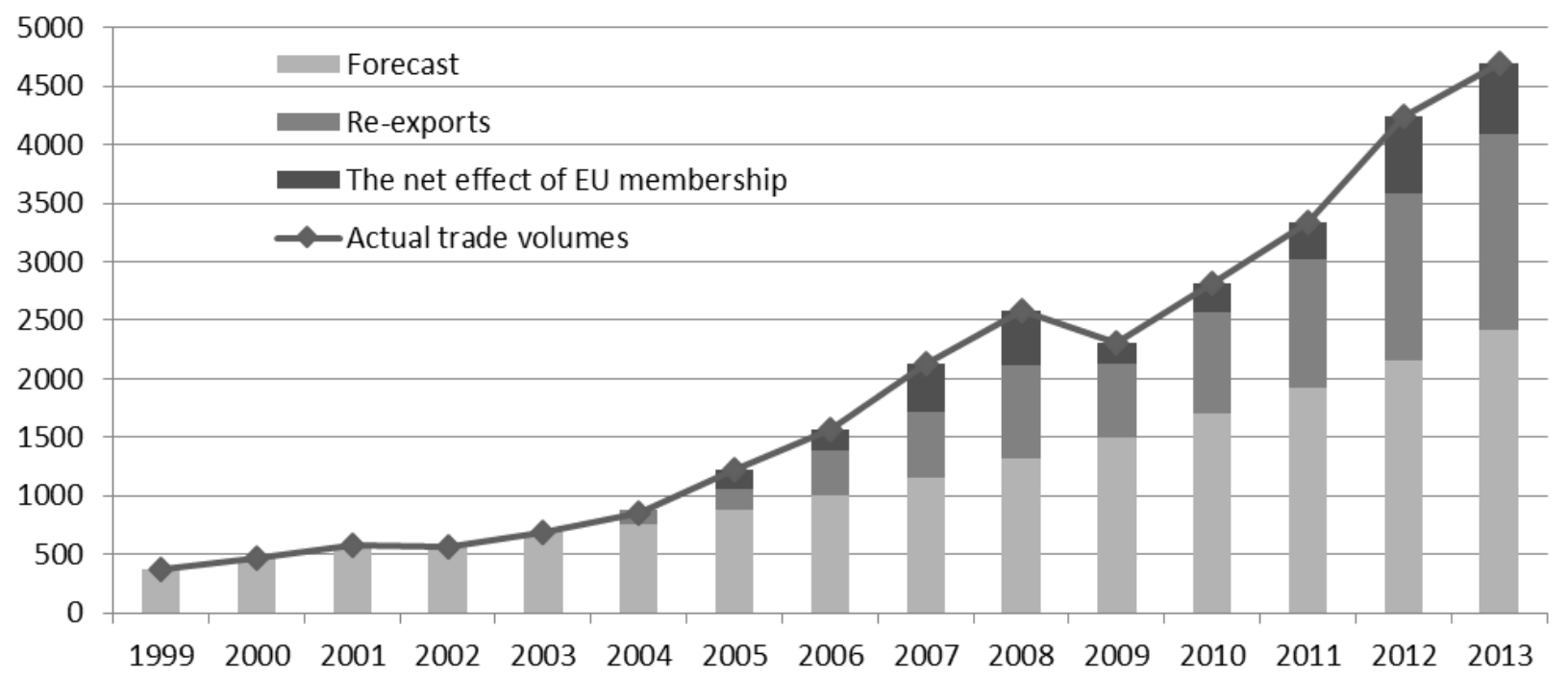

Source: own calculations based on Department of Statistics of Lithuania, 2015. 
The net effect of the EU membership, based on trend analysis, occurred in 2005 and grew until 2008. The majority of changes in the country's specialization also occurred since 2005 and this leads to the conclusion that EU integration had a positive influence on the specialization of Lithuanian exports of agricultural and food products. Global financial economic crisis strongly affected the Lithuanian origin agricultural and food exports as well as re-exports, but the rapid recovery observed from 2010. The growth rate of mentioned indicators accelerated in 2012 and 2013, but it suspended in 2014 because the restrictions on trade from the Russian Federation side (Figure 3).

In summary, Lithuanian agricultural and food exports got a positive benefit from the trade liberalization processes and has achieved a synergy effect with the EU membership, while re-exports was a contributed factor.

\section{Conclusions}

A small open economy usually has insufficient resources to produce a wide range of goods and services in order to meet domestic consumption and investment needs. Therefore, in order to bring the desired products, the country must accordingly be able to offer foreign markets certain goods and services for which the proceeds financed by the necessary imports. Therefore, exports from small open economies considered as the main source of foreign exchange, especially for a transition economy such as Lithuania. No exception is the export of Lithuanian agricultural and food products, which monitors the changes both before and after accession to the EU.

Necessary preconditions for effective development of international trade are: opening of markets, specialisation and economies of scale. The author has determined that economic integration is an important aspect of change of the international trade conditions. Despite many efforts of liberalizing foreign trade of agricultural and food products in early nineties and the membership in WTO in 2001, the real benefit for enlarged trade volumes was get after Lithuania entered the EU. Agricultural and food product exports and imports volumes rose intensively, on average 23 per cent for exports and 21 per cent for imports during the period 2004-2013.

The analysis show, that agricultural sector of Lithuania has contributed to creation of an open market, has not applied any market protection measures. Further free trade agreements between the EU and other countries of the world will imply growing competition on the common market. Paying the attention to notification of the consumers of the quality, distinctiveness of the Lithuanian agricultural and food products, their benefit to the consumers and valuable properties, is of the major importance. 
As Lithuania has no powers in formation of the international commercial policy, it should take care of increasing the domestic competitiveness supported by applying effective diplomatic and management decisions.

\section{References}

ANDERSON, K. (2010). Globalization's effects on world agricultural trade, 1960-2050. The Royal Society. Vol. 365.

BALDWIN, R. (2014). Trade and industrialization after globalization's second unbundling: how building and joining a supply chain are different and why it matters. In Feenstra, R. C.; Taylor A. M. (eds), Globalization in an Age of Crisis: Multilateral Economic Cooperation in the Twenty-First Century. University of Chicago Press, p. 165-212.

BOJNEC Š.; FERTÖ I. (2014). Export competitiveness of dairy products on global markets: the case of the European Union countries. Journal of Dairy Science, Vol. 97, No. 10. DUI: 10.3168/jds.2013-7711

DAMURI, Y. R. (2012). 21st Century Regionalism and Production Sharing Practice. CTEI Working Papers, CTEI-2012-4. P. 46.

DROŽDZ, J., MIŠKINIS, A. (2011). Benefits and Threats of Free Trade. Ekonomia, Vol. 2(14), p. 40-48.

EUROPEAN COMMISSION (2013). Trade development and regional integration in Lithuania. Development and cooperation. Europe Aid. 2013, Brussels.

KRUGMAN, P. (1991). Is Bilateralism Bad? In International Trade and Policy, edited by E. Helpman and A. Razim. Cambridge: MIT Press.

LASKIENĖ, D. (2010). Ryšys tarp tiesioginių užsienio investiciju ir investicijas priimančios šalies tarptautinès prekybos: Lietuvos atvejis. Economics \& Management. Vol. 15, p. 140-144.

LEAMER, E. E. (1995). The Heckscher-Ohlin theory and practice. Princeton Studies in International Finance. No. 77 , p. 60.

MOLENDOWSKI, E. (2014). The Visegrad Group Countries - Changes in Intra-industry Competitiveness of their Economies During the World Financial and Economic Crisis. Procedia - Social and Behavioral Sciences, Volume 110, p. 1006-1013. DOI: 10.1016/j.sbspro.2013.12.947

POCZTA-WAJDA, A. (2014). Assistance to agriculture in countries of a different development level and trends in world trade with agricultural products. Stowarzyszenie ekonomistów rolnictwa $i$ agrobiznesu. Roczniki Naukowe, Vol. XVI (6), p. 403-408.

RICARDO, D. (1821). On the Principles of Political Economy and Taxation. London: John Murray.

SMITH, A. (1776). An Inquiry into the Nature and Causes of the Wealth of Nations (1904 ed.). London: Library of Economics and Liberty. 5th edition. 
STOLPER, W. F.; SAMUELSON, P. A. (1941). Protection and real wages. The Review of Economic Studies. Oxford Journals. 9 (1): 58-73. DOI:10.2307/2967638.JSTOR2967638.

TRAVKINA, I. (2015). Export and GDP growth in Lithuania: short-run or middle-run causality? Entrepreneurship and Sustainability Issues, Vo. 3(1), p. 74-84. DOI: 10.9770/jesi.2015.2.4(7)

TRAVKINA, I., TVARONAVIČIENĖ, M. (2011). Export competitiveness and domestic productivity facets: case of Lithuania. Journal of business economics and management. Vol. 12(1), p. 49-68. DOI: $10.3846 / 16111699.2011 .555360$

VINCIŪNIENĖ, V.; DADURKAITĖ, J. (2011). Globalizacijos poveikis Lietuvos žemès ūkio ir maisto produktų užsienio prekybai. Management theory and studies for rural business and infrastructure development, Vol. 1 (25), p. 239-252. 